Pediat. Res. $1:$ 5-13 (1967)

Blood group cerebral palsy

choreoathetosis

dehydrogenase glucose-6-phosphate

hyperuricacidemia

self-mutilation

sex-linked inheritance

uric acid

\title{
Genetics of an X-Linked Disorder of Uric Acid Metabolism and Cerebral Function
}

\author{
W. L. Nyhan, J. Pesek, L. Sweetman, D. G. Carpenter and C.H. Carter \\ Departments of Pediatrics and Biochemistry \\ University of Miami School of Medicine, Miami, Florida \\ and The Sunland Hospital, Orlando, Florida
}

Extract

A syndrome of mental retardation, spastic cerebral palsy, choreoathetosis, and self-destructive biting has recently been described in children with elevated concentrations of uric acid in the blood. It is the purpose of this report to describe genetic studies which support an X-linked recessive mode of transmission.

Two new pedigrees have been constructed following the study of propositi. Patients D. B. and G.W. were studied at 5 years of age; the concentration of uric acid in the plasma was 9.9 and $11.7 \mathrm{mg} \%$ respectively.

The excretion of uric acid in the urine of patient D.B. ranged from 546 to $847 \mathrm{mg}$ per 24 hours, with a mean excretion of uric acid of $3.02 \mathrm{mg}$ per $\mathrm{mg}$ of creatinine. The specific activity of the uric acid in the urine after administration of glycine-U-C $\mathrm{C}^{14}$ was maximal in the first 12 hours and amounted to $118 \mathrm{cpm}$ per $\mathrm{mg}$. Cumulative recovery of radioactivity in uric acid amounted to 1.97 percent in 7 days. The difference between patient and controls is of the order of magnitude of 200 times.

Genetic transmission in an X-linked pattern was suggested from study of pedigrees (fig. 4 and fig. 5). Among the relatives of D. B., there were 15 affected individuals, all males. In the family of G.W., the disease was observed exclusively in males and, in each instance, transmission was through a female.

In a trait transmitted as an X-linked recessive, one-fourth of the sons and all carrier females are expected to be affected. In this test of the hypothesis, the observed proportion of affected and unaffected grandsons did not differ significantly from this expectation.

The results of testing with $\mathrm{Xg}^{\mathrm{a}}$ antiserum indicated that throughout most of the kindred the $\mathrm{X}$ chromosome carrying the pathologic hyperuricemic gene also carried the silent Xg gene. Recombination must be invoked to explain case III-15, who was $\mathrm{Xg}(\mathrm{a}+)$ and had an $\mathrm{Xg}(\mathrm{a}+)$ son and an involved son.

Neither the concentration of uric acid in the plasma nor the excretion of uric acid in the urine were useful in the detection of the abnormal gene. However, these data suggest that there may be some abnormality in uric acid metabolism in the heterozygote, but that it is not regularly possible to detect the presence of the abnormal gene by measuring the excretion of uric acid in the urine. The adult males were all found to excrete less uric acid than any of the groups of females.

The observations recorded provide further confirmation for the concept that the disorder under study is a distinct disease entity. Genetic data accumulating indicate that the disorder is inherited in an X-linked recessive pattern. 
Speculation

This condition has now been observed to present all the clinical manifestations of gout, including hyperuricemia, urinary tract crystals and calculi, renal failure, arthritis and tophi. It differs in the age of onset and the involvement of the central nervous system. Most gout in adults appears to be renal in origin; some reflects an overproduction of uric acid. The overproduction of uric acid in this condition greatly exceeds that of any form of gout in adults. It appears likely that the mechanism of overproduction will be found likewise to be different. In the presence of X-linked transmission, it should be possible to develop methods which detect the heterozygous carrier.

A syndrome of mental retardation, spastic cerebral palsy, choreoathetosis, and self-destructive biting has recently been described in children with elevated concentrations of uric acid in the blood [5]. Additional experience has confirmed the conclusion that this is a distinct disease entity $[3,4,7,8,11]$. Metabolic studies have indicated markedly increased turnover of uric acid and a striking overproduction of uric acid from glycine $[5,8]$. These observations indicate an abnormality in the biosynthesis of purines. It is the purpose of this report to describe genetic studies which support an X-linked recessive mode of transmission.

\section{Case Reports}

Two new pedigrees have been constructed following the study of propositi ascertained by survey of the Sunland Hospital at Orlando.

Patient D. B. (kindred JHLBC, IV-33) was studied at 5 years of age. During infancy he had appeared well except that he cried quite a lot until 4 months, when he could not hold his head and was thought to be retarded. Spasticity was noted at 9 months. Generalized convulsions began at 3 years of age, subsiding after one year. He began to bite his left index finger and his lower lip shortly after the onset of seizures. At 3 years, he was getting about in a walker; at 5 years, he could not sit unassisted.

The patient was a well-proportioned, $14.1 \mathrm{~kg}$ white male with athetoid cerebral palsy (fig. 1). He was severely mentally retarded; in psychometric evaluation by Dr. Frank Loefrler, he appeared to function at an 18-month level, which would represent a DQ of 30 . The lower lip was disfigured; a portion had been bitten off. There was a laceration of the left index finger. Biting behavior was observed to follow a regular pattern. He was generally calm and quiet, but on removal of restraints, he became extremely excited and screamed in terror; nevertheless, he bit vigorously at his finger. His extremities were spastic and deep tendon reflexes were increased symmetrically. There were bilateral Babinski responses. Athetoid movements were not marked at rest, but increased with intention in response to pleasurable or painful stimuli.

The diaper was crusted with orange crystalline material, which was assayed. There was a single uric acid spot on paper chromotography and quantitatively over 90 percent of the dry material was uric acid. The blood urea nitrogen was 14.5 and the plasma uric acid $9.9 \mathrm{mg}$ per $100 \mathrm{ml}$.

Patient G.W. (kindred LW, IV-19) was studied at 5 years. He appeared listless at birth and developed slowly. By 15 months, he was able to pull himself around on the floor and had 3 to 4 words, but at 5 years he functioned less well. He had grand mal seizures.

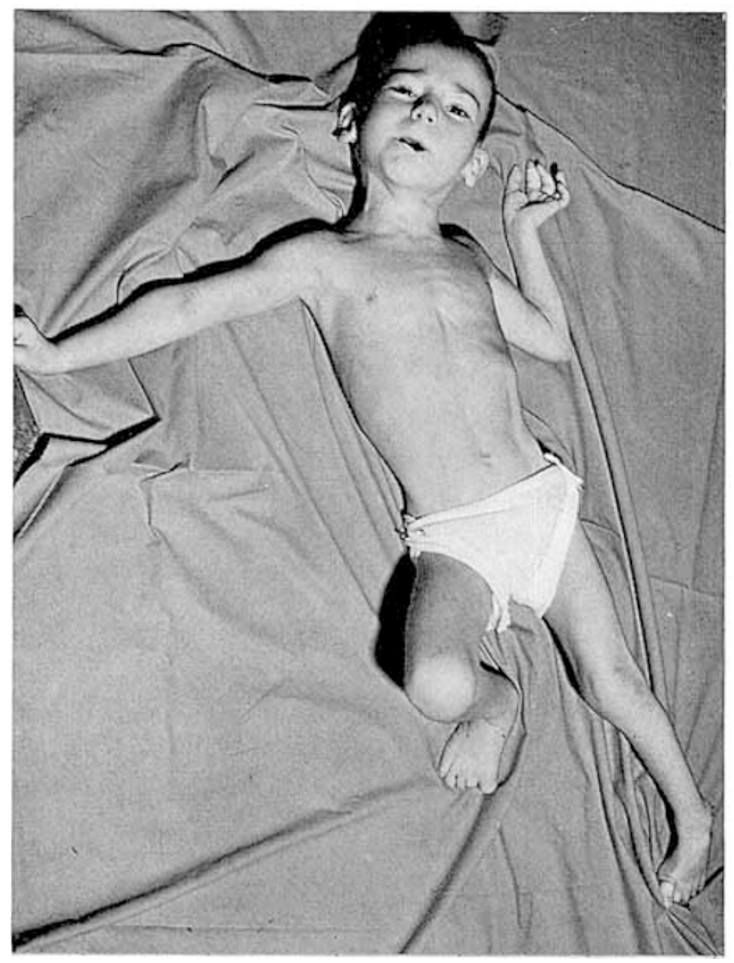

Fig. 1. Patient D. B. at 5 years of age. Photograph was taken during athetoid movement. There is a loss of tissue in the bitten lower lip. 
He appeared to be a well-proportioned $15.2 \mathrm{~kg}$ white male. He had moderate spasticity and a symmetrical increase in the deep tendon reflexes. Choreoathetosis was present, particularly on intention. Examination of the lower lip revealed shortening and loss of tissue which was observed in hospital to follow biting. There were scars on the hands and arms. Psychometric evaluation revealed profound deficit in intellectual function and a developmental age estimated at under one year.

The blood urea nitrogen was 13.5 and the plasma uric acid $11.7 \mathrm{mg}$ per $100 \mathrm{ml}$.

\section{Materials and Methods}

The metabolic abnormality in patient D.B. was documented in the Clinical Research Unit of the University of Miami, in accordance with the protocol previously described [5]. A 'purine free' diet was used throughout. Methods employed for the isolation of uric acid, its assay, and its formation from glycineU-C ${ }^{14}$ have been described [5]. Pedigrees were constructed on the basis of data and pictures obtained from the families of the probands and from records of institutions for the retarded, and by direct observation. Direct observation was virtually complete for living members of the family of D.B. on whom field trips were undertaken. The family of G.W. is scattered over 3 distant states and has not yet been visited in detail. Blood typing was carried out by Miss Pauline Schmidt of Dade Reagents, Inc., Miami, Florida. The following typings were performed on members of the family of D. B.: A B O G D E c e C ${ }^{w}$ M N S s P Le Le Jk $\mathrm{Lu}^{\mathrm{a}}$ $\mathrm{Lu}^{\mathrm{b}} \mathrm{K}$ k Fy $\mathrm{Fy}^{\mathrm{b}}$ and $\mathrm{Xg}^{\mathrm{a}}$. The anti-Xga serum was obtained from Pfizer Diagnostics through the courtesy of Dr. Amos Cahan. The erythrocytes of these family members were screened for glucose-6-phosphate dehydrogenase (G-6-PD) deficiency using the method of Oskr and Growney [9] and in about half of them, the screening test was confirmed using the quantitative method of GLOCK and MCLEAN [1]. Color vision was assessed using H-R-R Pseudoisochromatic plates under standard illumination from a New England Easel Lamp (American Optical Co.) and The Farnsworth Dichotomous Test. Twenty-four hour urine samples were obtained from family members during a 24-hour period in which purine intake was limited by the exclusion of meat and fish from the diet. Total volumes were recorded promptly on completion and aliquots of urine, as well as plasma samples were frozen until assayed. Erythrocytes obtained were washed twice with saline and separated into two aliquots. One was diluted 1:1 with glycerol citrate solution and frozen for blood typing. The other was used for microhematocrit, the screening test for G-6-PD, and for a 1:20 hemolysate for quantitative assay of G-6-PD.

\section{Results}

Metabolic Investigation of Patient D. B. The concentration of uric acid in the serum was determined 5 times in a 7 -month period. It varied from 7.4 to $9.9 \mathrm{mg}$ per 100 $\mathrm{ml}$. The concentration of uric acid in the cerebrospinal fluid was $0.3 \mathrm{mg}$ per $100 \mathrm{ml}$. His excretion of uric acid in the urine ranged from 546 to $847 \mathrm{mg}$ per 24 hours with a mean of $691 \mathrm{mg}$ per 24 hours during a 6-day period of careful collections on a 'no purine' diet. Excretion of over $600 \mathrm{mg}$ of uric acid per 24 hours in a gouty adult of approximately $70 \mathrm{~kg}$ is the criterion for classification as a hyperexcretor [2, 13]. The mean excretion of $691 \mathrm{mg}$ per day is 3 times that observed in control children of the same size as the patient [5]. Adjustment of the data for body weight yielded a range of 36.4 to 56.5 and a mean of $46.0 \mathrm{mg}$ per $\mathrm{kg}$ per 24 hours, which is virtually identical to data obtained on other children with this disorder [5,8]. Calculated in terms of creatinine excretion, his mean excretion of uric acid was $3.02 \mathrm{mg}$ per $\mathrm{mg}$ of creatinine. Control children and control adults, even with gout, generally excrete less than $1.0 \mathrm{mg}$ of uric acid per $\mathrm{mg}$ of creatinine.

The synthesis of uric acid was studied by determining the isotope content of urinary urate following the intravenous injection of $2 \mu \mathrm{c}$ per $\mathrm{kg}$ of glycine-U-C $\mathrm{C}^{14}$. The specific activity of the uric acid isolated was maxi$\mathrm{mal}$ at $118 \mathrm{cpm}$ per $\mathrm{mg}$ in the first 12 hours after injection. The specific activities found differed clearly from those observed in controls [5] and there was no overlap throughout the period of study. At the peak, the specific activity in the patient approximated 4 times that of controls. In experiments of this type, it has not been possible to distinguish adults with gout from control adults [13]. Therefore, the cumulative recovery of the isotope of glycine in urinary uric acid has been employed to characterize those in whom gout is clearly associated with overproduction of uric acid. Data obtained on D.B. are compared with those of controls in fig. 2. In the patient, 1.97 percent of the isotope administered was found in urinary uric acid in the 7 days of study. Some urine was lost during the collection of the second half of the third day, so that the true total should be somewhat higher. Control subjects converted only 0.01 percent of the isotope of glycine to uric acid in this period. The curve obtained for D.B. in fig. 2 looks like a duplicate of those found in 4 other patients studied $[5,7,8]$. The difference between patient and controls is of the order of magnitude of 200 times. 


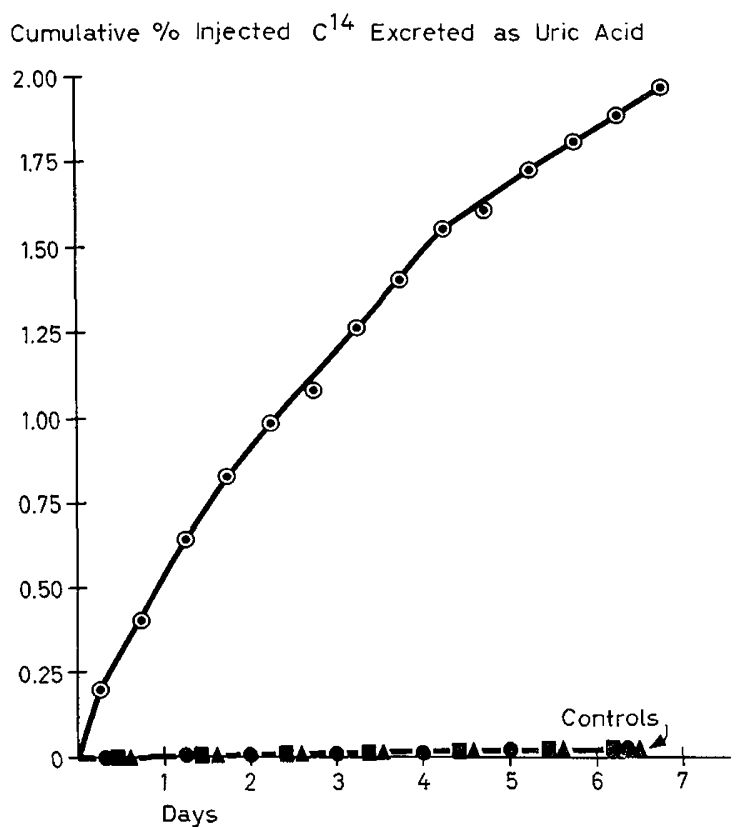

Fig. 2. The cumulative excretion of $\mathrm{C}^{14}$ in urinary uric acid in patient D. B. and in 3 control individuals following the administration of glycine-U-C ${ }^{14}$.
Genetic studies. The first suggestion that this disorder might be transmitted in an X-linked pattern was contained in the second report [8]. A pedigree (fig. 3) con-

Kindred $\mathrm{S}$.

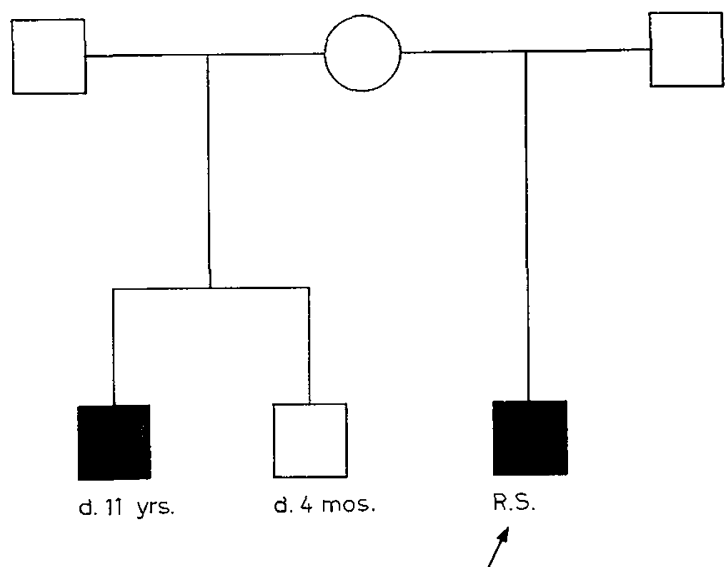

Fig.3. Pedigree of the family of R.S. constructed from information contained in the report of the case [8].

Table I. Clinical data affected members of family of D. B.

\begin{tabular}{|c|c|c|c|c|c|c|}
\hline $\begin{array}{l}\text { Family } \\
\text { member }\end{array}$ & $\begin{array}{l}\text { Mental } \\
\text { retardation }\end{array}$ & $\begin{array}{l}\text { Athetoid } \\
\text { cerebral palsy }\end{array}$ & $\begin{array}{l}\text { Self- } \\
\text { mutilation: } \\
\text { lips, hands }\end{array}$ & Other features & Ascertainment & $\begin{array}{l}\text { Current } \\
\text { status }\end{array}$ \\
\hline $\begin{array}{l}\text { II- } 1,4-8 \text {, } \\
\text { and } 10\end{array}$ & + & + & + & $\begin{array}{l}\text { mutilation of tongue; II- } 3 \text { relates } \\
\text { finding major portion brother's } \\
\text { tongue on ground }\end{array}$ & historical & $\begin{array}{l}\text { all died } \\
\text { under } \\
5 \text { years }\end{array}$ \\
\hline IV -3 & + & + & + & $\begin{array}{l}\text { abdominal pain; recurrent colicky } \\
\text { attacks. Tophi general over joints, } \\
\text { ears; those on hands discharged } \\
\text { white material. Mutilation of } \\
\text { tongue-loss of large portion. Acute } \\
\text { inflammation of joints-periodic. }\end{array}$ & $\begin{array}{l}\text { historical } \\
\text { photographs }\end{array}$ & $\begin{array}{l}\text { died at } \\
24 \text { years }\end{array}$ \\
\hline IV-25 & $t$ & + & + & tophus golf ball size-left ear & $\begin{array}{l}\text { examined; } \\
\text { photographed }\end{array}$ & 21 years \\
\hline IV -27 & + & + & + & & $\begin{array}{l}\text { examined; } \\
\text { photographed }\end{array}$ & 14 years \\
\hline IV -29 & + & + & + & & $\begin{array}{l}\text { examined; } \\
\text { photographed }\end{array}$ & 12 years \\
\hline IV -33 & + & + & + & $\begin{array}{l}\text { propositus; plasma uric acid } \\
7.4-9.9 \mathrm{mg} / 100 \mathrm{ml}\end{array}$ & $\begin{array}{l}\text { examined; } \\
\text { photographed }\end{array}$ & 6 years \\
\hline IV-35 & + & + & & seizures & historical & $\begin{array}{l}\text { died at } \\
3 \text { years }\end{array}$ \\
\hline $\mathrm{V}-1$ & + & + & ? & & $\begin{array}{l}\text { historical; } \\
\text { photographs }\end{array}$ & $\begin{array}{l}\text { died at } \\
6 \text { years }\end{array}$ \\
\hline$V-2$ & + & 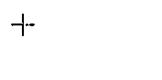 & + & $\begin{array}{l}\text { plasma uric acid } \\
8.9-10.3 \mathrm{mg} / 100 \mathrm{ml}\end{array}$ & $\begin{array}{l}\text { examined; } \\
\text { phostographed }\end{array}$ & 11 years \\
\hline
\end{tabular}




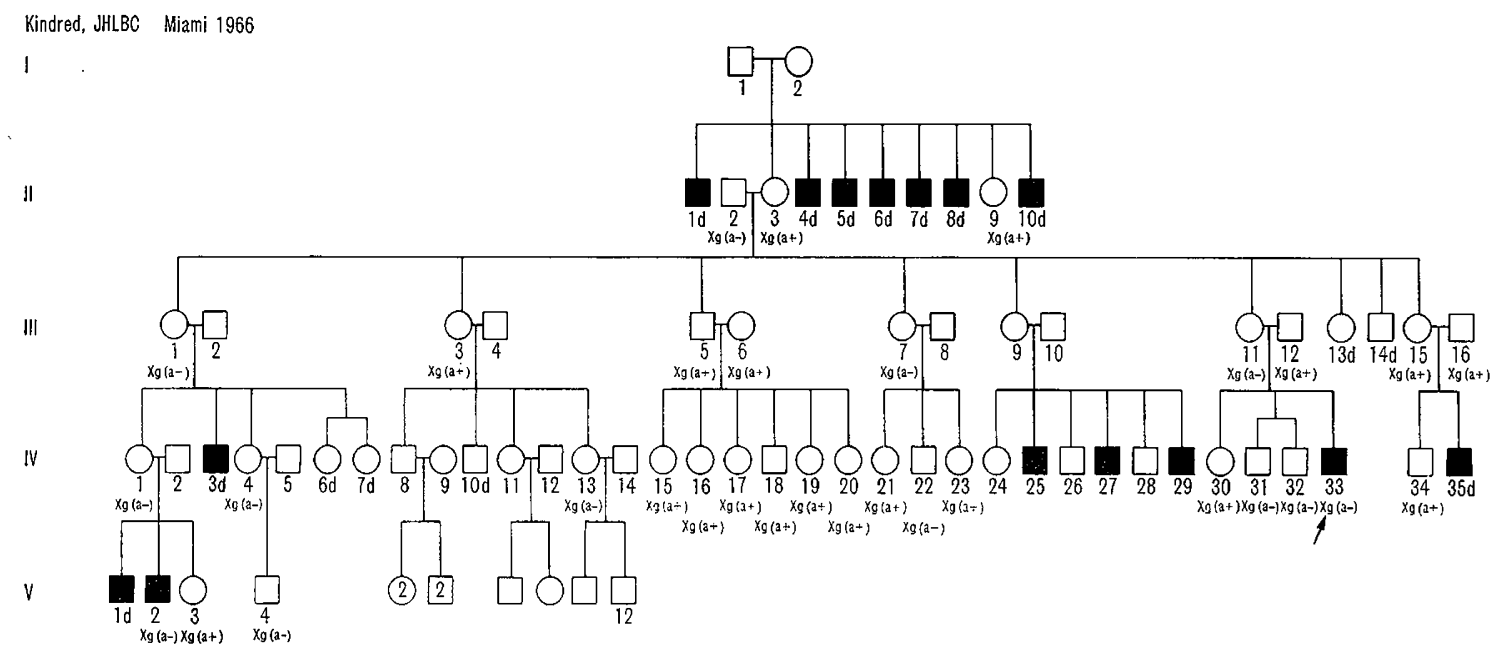

Fig.4. Pedigree of the family of D. B.

structed from the data illustrates the transmission of the disorder to two sons of one mother by two fathers. The third son died at 4 months, which is too early to tell by historical data whether or not he had the disease.

This observation was extended when information became available on the families of D.B. (fig. 4) and G.W. (fig. 5). Among the relatives of D.B., there were 15 affected individuals. All were males. Clinical observations on these family members are summarized in table I. Among other members of the family, all appeared clearly to be uninvolved. The second son (IV-10) of III-3 died at 9 months of pneumonia, but was developing normally prior to that acute disease, as was III-14 who died of meningitis at the age of 9 months. Furthermore, II- 9 had 8 children and 9 grandchildren, all of whom were healthy.

In the family of G.W. (fig. 5), 4 generations are illustrated in 3 of which were involved children. Again the disease was observed exclusively in males and, in each instance, transmission was through a female. These women include the sister of involved boys in generation I, her daughters, II-2, II-3 and II-8, and 2 of the daughters of II-8. There were 9 involved children in this family. Mental retardation, cerebral palsy, and lip biting with destruction of the lower lip were prominent characteristics.

A 'grandmother test' performed on the data from both of these large pedigrees is indicated in table II. In a trait transmitted as an X-linked recessive, onefourth of the sons of all daughters of carrier females are expected to be affected. In this test of the hypothesis, the observed proportion of affected and unaffected grandsons did not differ significantly from this expectation.

The results of testing with $\mathrm{Xg}^{\mathrm{a}}$ antiserum in kindred
JHLBC are given in fig. 4. The other blood typings were consistent with the maternity and paternitystated. There was no evidence of linkage with the hyperuricemic abnormality of other blood types. The evidence is that throughout most of the kindred the $\mathrm{X}$ chromosome carrying the pathologic hyperuricemic gene also

Table II. Proportion of affected and unaffected male grandsons of carriers through their daughters

\begin{tabular}{|c|c|c|c|c|c|}
\hline Kindred & $\begin{array}{l}\text { Grand- } \\
\text { mother }\end{array}$ & Daughter & Affected & $\begin{array}{l}\text { ons } \\
\text { Unaffected }\end{array}$ & Total \\
\hline \multirow[t]{10}{*}{ JHLBC } & I-1 & II-3 & 0 & 2 & 2 \\
\hline & & II-9 & 0 & 4 & 4 \\
\hline & II-3 & III-1 & 1 & 0 & 1 \\
\hline & & III-3 & 0 & 2 & 2 \\
\hline & & III-7 & 0 & 1 & 1 \\
\hline & & III-9 & 3 & 2 & 5 \\
\hline & & III-11 & 1 & 2 & 3 \\
\hline & & III-15 & 1 & 1 & 2 \\
\hline & III-1 & IV-1 & 2 & 0 & 2 \\
\hline & & IV -4 & 0 & 1 & 1 \\
\hline \multirow[t]{7}{*}{ LW } & $\mathrm{I}-1$ & II-2 & 1 & 1 & 2 \\
\hline & & II-3 & 2 & 1 & 3 \\
\hline & & II-5 & 0 & 1 & 1 \\
\hline & & II-7 & 0 & 3 & 3 \\
\hline & & II-8 & 0 & 2 & 2 \\
\hline & II-8 & III-17 & 2 & 2 & 4 \\
\hline & & III-18 & 2 & 3 & 5 \\
\hline \multirow{3}{*}{$\begin{array}{l}\text { Totals for } \\
\text { Expected }\end{array}$} & und . & . . & 15 & 28 & 43 \\
\hline & $d$. & . . . & 10.75 & 32.25 & 43 \\
\hline & & & & \multicolumn{2}{|c|}{$\begin{array}{c}\chi^{2}=2.24 \\
0.2>p>0.1\end{array}$} \\
\hline
\end{tabular}


Table III. Uric acid in plasma and urine in family of D.B.

\begin{tabular}{|c|c|c|c|}
\hline \multirow[t]{2}{*}{ Family member } & \multicolumn{2}{|c|}{ Urinary uric acid } & \multirow{2}{*}{$\begin{array}{l}\text { Plasma } \\
\text { uric acid } \\
\mathrm{mg} / 100 \mathrm{~m}\end{array}$} \\
\hline & $\mathrm{mg} / 24 \mathrm{~h}$ & $\begin{array}{l}\mathrm{mg} / \mathrm{mg} \\
\text { creatinine }\end{array}$ & \\
\hline \multicolumn{4}{|c|}{$\begin{array}{l}\text { Carriers, presumed } \\
\text { heterozygotes }\end{array}$} \\
\hline II -3 & 364 & 0.652 & 8.48 \\
\hline III-1 & 389 & 0.655 & 5.93 \\
\hline III-11 & 497 & 0.504 & 4.78 \\
\hline III-15 & 241 & 0.294 & 5.32 \\
\hline IV -1 & 287 & 0.476 & 5.35 \\
\hline \multicolumn{4}{|c|}{ Sisters of carriers } \\
\hline II-9 & 286 & 0.276 & 4.78 \\
\hline III-3 & 437 & 0.369 & 6.85 \\
\hline III-7 & 373 & 0.364 & 4.51 \\
\hline IV -4 & 207 & 0.812 & 4.74 \\
\hline \multicolumn{4}{|c|}{ Unrelated female, wife } \\
\hline III-6 & 470 & 0.454 & 4.53 \\
\hline \multicolumn{4}{|c|}{ Other adult females } \\
\hline IV-13 & 207 & 0.357 & 3.78 \\
\hline IV -15 & & & 6.74 \\
\hline IV-16 & & & 3.28 \\
\hline IV-17 & 424 & 0.500 & 4.28 \\
\hline IV-21 & 294 & 0.311 & 4.49 \\
\hline IV -23 & 204 & 0.350 & 5.18 \\
\hline \multicolumn{4}{|l|}{ Adult males } \\
\hline II-2 & & 0.277 & 4.99 \\
\hline III-5 & & & 5.10 \\
\hline III-12 & 337 & 0.249 & 5.64 \\
\hline III-16 & 190 & 0.200 & 4.53 \\
\hline IV -5 & 113 & 0.264 & 6.35 \\
\hline IV -22 & 160 & 0.197 & 4.53 \\
\hline \multicolumn{4}{|c|}{ Male children } \\
\hline IV -18 & 257 & 0.457 & 5.64 \\
\hline IV -31 & 126 & 0.680 & 4.53 \\
\hline IV -32 & 208 & 0.636 & 4.05 \\
\hline IV -34 & 226 & 0.309 & 5.32 \\
\hline$V-4$ & & & 3.82 \\
\hline$V-11$ & 75 & 0.478 & \\
\hline \multicolumn{4}{|c|}{ Female children } \\
\hline IV -19 & 129 & 0.630 & 3.80 \\
\hline IV-20 & 170 & 0.643 & 3.76 \\
\hline IV -30 & 390 & 0.569 & 5.01 \\
\hline$V-3$ & & & 2.57 \\
\hline
\end{tabular}

Concentrations of uric acid in the serum were determined on 12 of these individuals at various times over the year prior to this study, and values virtually identical to those listed were obtained. Less than complete $24 \mathrm{~h}$ samples were obtained on II-2 and IV-17 and therefore these data are expressed only as mg per mg of creatinine.
$1 \quad$ Kindred, LW Miami 1966 (1)

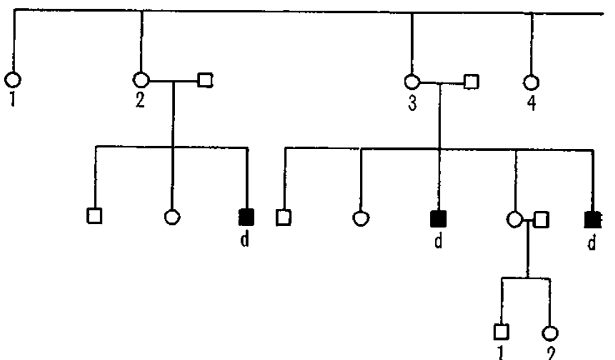

Fig.5. Pedigree of the family of G.W.

carried the silent $\mathrm{Xg}$ gene. The grandmother, II-3, sister of 7 involved boys was $\mathrm{Xg}(\mathrm{a}+)$ and her husband $\mathrm{Xg}(\mathrm{a}-)$. Analysis of her progeny indicates her genotype to be $\mathrm{XgXg}^{\text {a }}$. She must have carried the pathologic gene on a chromosome leading to $\mathrm{Xg}$ negativity, for her daughters, III-1 and III-11, were Xg (a-) and had involved boys who were also Xg (a-). Furthermore, her $\mathrm{Xg}(\mathrm{a}+)$ son, III-5, was healthy, and the 4 children and 8 grandchildren of her $\mathrm{Xg}(\mathrm{a}+)$ daughter, III-3, were also uninvolved. Her other Xg (a-) daughter, III-7, would be expected to have received, like III-1 and III-11, a nonhyperuricemic Xg-containing chromosome from their father and a hyperuricemic Xg-containing chromosome from their mother. Of course, in the case of these Xg (a-) mothers, heterozygous for the hyperuricemic gene, crossing over and recombination could not be assessed. Recombination must be invoked in the case of III-15, who was $\mathrm{Xg}(\mathrm{a}+)$ and had an $\mathrm{Xg}(\mathrm{a}+)$ son and an involved son.

The inheritance of the $\mathrm{Xg}^{\mathrm{a}}$ antigen in this family is shown in fig. 6 . These data are consistent with the Xlinked dominant hypothesis established by MANN $e t$ al. [6]. In matings of $\mathrm{Xg}(\mathrm{a}+) \times \mathrm{Xg}(\mathrm{a}+)$, there were no negative daughters. With an $\mathrm{Xg}(\mathrm{a}+)$ male $\mathrm{X}$ $\mathrm{Xg}(\mathrm{a}-)$ female, all male offspring were negative and

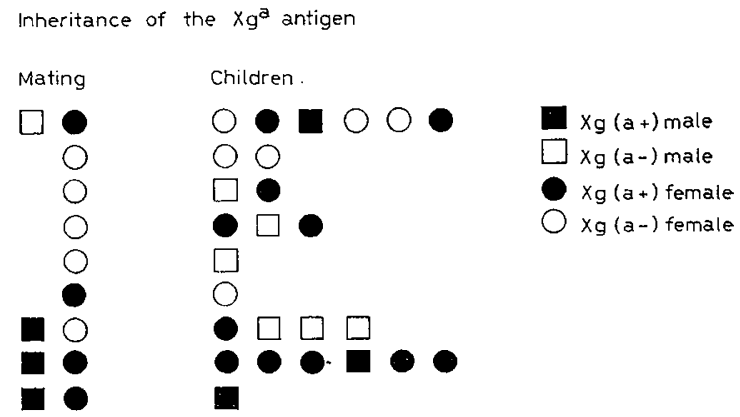

Fig.6. Results of testing with Anti-Xga serum in kindred J.H.L.B.C. 


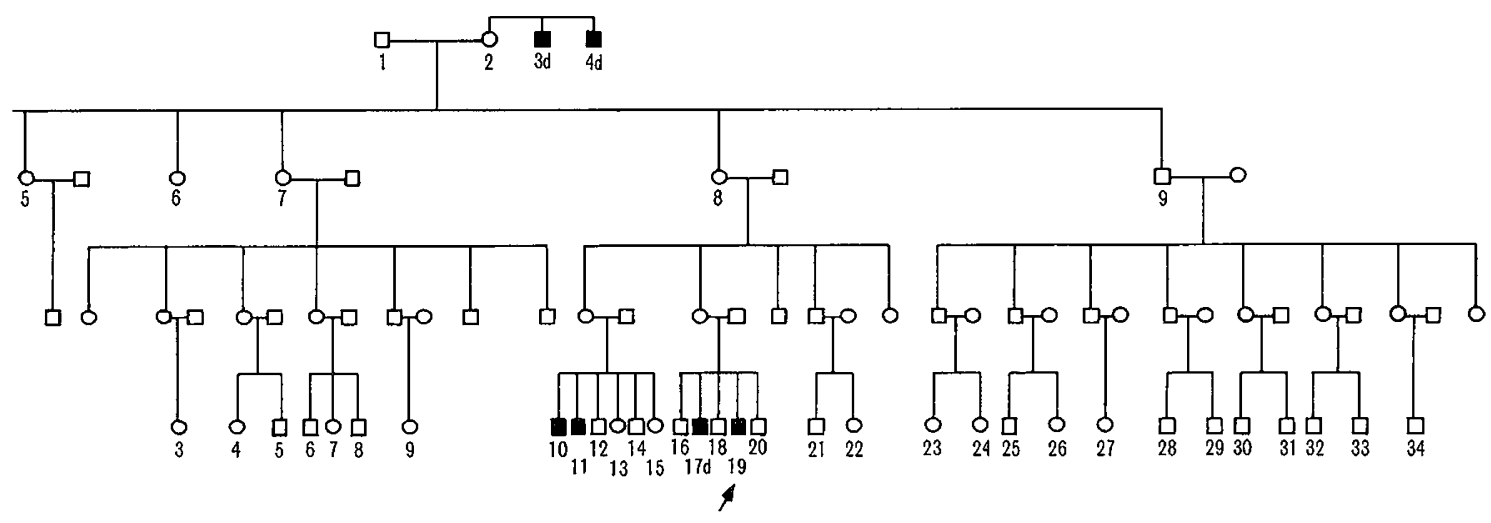

all female positive. With an Xg (a-) male X Xg $(\mathrm{a}+)$ female, all possibilities are possible. Of negative females, the sons and fathers must be negative and of positive males, the mothers and daughters must be positive.

The screening test for glucose-6-phosphate dehydrogenase was normal in each of the family members for whom $\mathrm{Xg}^{\mathrm{a}}$ testing is listed in fig. 4. Quantitative assay for the enzyme in some of these was confirmatory, yielding values of 80 to $120 \mu$ per $100 \mathrm{ml}$ of erythrocytes, except for II-3 in whom the value was $294 \mu$ per $100 \mathrm{ml}$ of erythrocytes. Testing for color vision was likewise not rewarding in the evaluation of X-chromosomal transmission in this kindred.

Concentrations of uric acid in the plasma and excretion in the urine in family members. The results of this survey are indicated in table II. It is clear that the concentration of uric acid in the plasma is not useful in the detection of the abnormal gene. Concentrations in known carriers of generations III and IV were not different from those of other members of the family. Only II-2 had an elevated level, which was $8.48 \mathrm{mg}$ per $100 \mathrm{ml}$ at 75 years of age at the time of this study and $6.2 \mathrm{mg}$ per $100 \mathrm{ml}$ approximately one year previously. The only other individuals with concentrations over $6.0 \mathrm{mg}$ per $100 \mathrm{ml}$ were: III-3, whose $\mathrm{Xg}^{\mathrm{a}}$ positivity, 4 children and 8 grandchildren, all of whom were uninvolved, suggest that she did not receive the abnormal gene; IV-15, who received her $\mathrm{X}$ chromosome of this family from her father; and IV -5 , who is the husband of IV -4 and not a product of this family. The distinctly elevated concentration of uric acid in the plasma of II-3 suggests the possibility that uric acid metabolism may be abnormal in the heterozygote, but elevated concentrations become relatively common with advancing age.

The excretion of uric acid in the urine failed also to distinguish the heterozygous carrier. None of the individuals studied excreted more than $500 \mathrm{mg}$ of uric acid in 24 hours. Identified carriers excreted 241 to $497 \mathrm{mg}$ per 24 hours. These values are certainly comparable to those of their sisters, who may or may not carry the abnormal gene, and to those of the other adult females who almost certainly do not carry the gene, such as III-6, who is related to the family only through having married III-5, and her daughter, IV-17. Considered in terms of mg excreted per mg of creatinine, the values in the series of identified carriers were among the highest of the adults studied. The range was from 0.294 to 0.655 with a mean of $0.516 \mathrm{mg}$ per $\mathrm{mg}$ of creatinine. On the other hand, there was considerable overlap; the value for IV-4, who could, of course, be a heterozygote, was 0.812 , and those of III- 6 and IV-17 were 0.454 and $0.500 \mathrm{mg}$ per $\mathrm{mg}$ of creatinine, respectively. These data suggest that there may be some abnormaljty in uric acid metabolism in the heterozygote, but that it is not regularly possible to detect the presence of the abnormal gene by measuring the excretion of uric acid in the urine.

Analyses of urate excretion were also done on some of the family members at times in which purine intake was not restricted. The mother of the propositus had a 24-hour excretion of $995 \mathrm{mg}$, while she was eating a regular diet. Her sister, III-7, excreted $852 \mathrm{mg}$ per 24 hours, and III-7's daughter, IV-21, $493 \mathrm{mg}$ per 24 hours. Values obtained from the father of the propositus and his twin sons were $0.304,0.408$ and $0.378 \mathrm{mg}$ per mg of creatinine, which did not differ greatly from those obtained with purine restriction. On the other hand, the sister, IV-30, of the propositus excreted 1.21 $\mathrm{mg}$ of uric acid per $\mathrm{mg}$ of creatinine on a regular diet. These observations indicate that control of the dietary intake of purines is essential for interpretable study of the excretion of uric acid in the urine.

The children in this study excreted relatively large amounts of uric acid per $\mathrm{mg}$ of creatinine excreted. Except for IV-34, who was 15 years of age, their excretions ranged from 0.457 to 0.680 with a mean of $0.585 \mathrm{mg}$ per mg of creatinine. This is consistent with previous observations [5] in which uric acid excretion 
in children was found to be relatively high when expressed as mg of uric acid per $\mathrm{kg}$ of body weight.

The adult males were all found to excrete less uric acid than any of the groups of females. The range of data for the males was a relatively narrow one from 0.197 to $0.277 \mathrm{mg}$ per $\mathrm{mg}$ creatinine with a mean of $0.237 \mathrm{mg}$ per $\mathrm{mg}$ of creatinine. The value for only one of the females, the 63-year-old, II-9, overlapped this range.

\section{Discussion}

The observations recorded provide further confirmation for the concept that the disorder under study is a distinct disease entity. Clinical manifestations are striking. There are variations in severity, even within a single family, but all of the patients have been incapacitated and have been among the severely retarded. Evidence of regression has been observed in a number of these patients, including the propositus, D. B. Marked spasticity and choreoathetosis have been uniform. Self-mutilating biting is the most unusual clinical characteristic and the one by which most patients have recently been detected. The onset of this bizarre behavior may be delayed as long as 3 years, as indicated by the course of D. B. and others, although it may be seen as soon as there are teeth. Certain clinical manifestations had not previously been reported. Two patients in this study had infantile colic or later, recurrent abdominal pain. These symptoms are consistent with the passage of large numbers of crystals and occasional calculi [8] along the urinary tract. Similar observations of infantile colic in this disorder have been made by Platou [10]. Destructive activity involving the tongue was seen for the first time in this study and involved a number of members of one kindred. Tophi have previously been rarely observed in this disorder. They were found in 2 patients in this study. There were a number in the patient reported by RILEX [12] and a number have developed in another patient currently under investigation [7]. The development of tophi appears to be a function of the duration of the disease.

The metabolic abnormality in this condition is evident in the amounts of uric acid in the blood and urine. Previous studies [5] have indicated very rapid turnover, as measured using uric acid-2- $\mathrm{C}^{14}$, which exceeded those encountered in gouty adults by approximately 6 times. The most unusual biochemical characteristic of the syndrome is the rate of formation of uric acid from glycine. In these patients, the difference from control approximates 200 times. These observations do not imply a disorder of glycine metabolism, but rather an overproduction of purine that should be demonstrable with any precursor of purine synthesis. The rates of uric acid formation are the highest reported in any condition. The curve for the patient in whom this was documented in this report is virtually identical to those found in the other patients studied with $\mathrm{C}^{14}$ glycine. This similarity is striking in a complicated 7-day metabolic conversion involving a number of enzymatic steps. It suggests the presence of an identical alteration involving a single step responsible for the overall rate of purine biosynthesis.

Genetic data accumulating indicate that this disorder is inherited in an X-linked recessive pattern. The three pedigrees illustrated in this report and kindreds observed by Hoefnagel et al. [4] and Shapiro et al. [14] are all consistent with this hypothesis. The evidence for X-linked inheritance includes the facts that: 1. the disease has been observed only in males; 2 . affected males inherit the disease only from their mothers; and 3. the grandmother test does not show a significant deviation from the ratio expected.

The data obtained from $\mathrm{Xg}^{\mathrm{a}}$ typing are consistent with the hypothesis that the abnormal hyperuricemic gene is on the $\mathrm{X}$-chromosome. A single recombination was demonstrated in this study. Other instances of crossing over might not be detectable in this family, in which so many of the carriers were $\mathrm{Xg}^{\text {a }}$ negative. Some $\mathrm{Xg}^{\mathrm{a}}$ typing in a family with this trait has also been carried out by Hoefnager. [4], who has not reported his data, but stated in discussion that crossover was observed. A much larger body of data will be required to establish the recombination fraction with any security. The testing of additional families would be of considerable interest, both to establish linkage and to contribute to the mapping of the $\mathrm{X}$ chromosome. The order of genes on the $\mathrm{X}$ chromosome is currently thought to be Xg-G-6-PD-deutan color blindnesshemophilia A. Ultimately, it should be possible to determine the relative position of this abnormal hyperuricemic gene on the chromosome and its relative distances from other genes.

The development of methods for the detection of the heterozygous carrier would be of interest as independent support for the concept of X-chromosomal transmission and from the point of view of genetic counseling. It has been suggested that this may be possible by assessment of the excretion of uric acid in the urine. HoefNagel et al. [4] reported excretions in 3 mothers of involved children of 500, 594 and $825 \mathrm{mg}$ per 24 hours, and SHAPIRo et al. [14] reported the mother of their proband to excrete $952 \mathrm{mg}$ of uric acid in the urine in 24 hours. Similar levels of excretion were observed in the mother of a propositus in this study and in her sister, while they were eating a regular diet. On modest restriction of dietary intake of purines, these women and all of the others in the kindred excreted quantities of uric acid well within the normal range. It would appear that control of the intake of purines 
is essential for the elucidation of this problem. We do not doubt the likelihood that there is a detectable abnormality of purine metabolism in the female heterozygous for the gene under consideration. Distinctly elevated 24 hours excretions of uric acid have been documented in this laboratory for some of the same mothers reported by HoefNager et al. [4] and other identified carriers, even under conditions of rigid control of dietary purine in a Clinical Research Unit. On the other hand, in the course of daily collections under the same conditions on the same mother, values as far apart as 330 and $650 \mathrm{mg}$ per 24 hours have been found. These observations indicate that the regular detection of the heterozygote is more complicated than the simple determination of the amount of uric acid excreted in the urine in 24 hours. Further investigation of this problem is in progress.

\section{Summary}

Two previously unreported kindreds have been described in which a number of children were affected with a disorder of uric acid metabolism and central nervous system function. The cardinal clinical features include mental retardation, spastic cerebral palsy, choreoathetosis and self-mutilating biting. Metabolic investigation of the propositus of the first family indicated a marked degree of overproduction of uric acid from $\mathrm{C}^{14}$-glycine. Genetic analysis indicated clearly that this is an X-linked recessive disorder of the male.

\section{References and Notes}

1. Grock, G.E. and MaLean, P.: Further studies on the properties and assay of glucose-6-phosphate dehydrogenase and 6-phospho-gluconate dehydrogenase of rat liver. Biochem.J. 55: 400 (1953).

2. Gutman, A.B.; Yu, T.F.; Black, H.; Yalow, R.S. and Berson, S. A.: Incorporation of glycine1- $\mathrm{C}^{14}$, glycine-2- $\mathrm{C}^{14}$ and glycine- $\mathrm{N}^{15}$ into uric acid in normal and gouty subjects. Amer. J. Med. 25: 917 (1958).

3. Hoefnagel, D.: Syndrome of athetoid cerebral palsy, mental deficiency, self-mutilation and hyperuricemia. J.ment. Defic. Res. 9: 69 (1965).

4. Hoefnagel, D.; Andrew, E. D.; Mrreault, N. G. and Berndt, W.O.: Hereditary choreoathetosis, self-mutilation and hyperuricemia in young males. New Engl.J. Med. 273: 130 (1965).

5. LESGH, M. and NyHAN, W.L.: A familial disorder of uric acid metabolism and central nervous system function. Amer. J. Med. 36: 561 (1964).

6. Mann, J.D.; Cahan, A.; Gelb, A. G.; Fisher, N.; Hamper, J.; Tippett, P.; SAnger, R. and Race, R.R.: A sex-linked blood group. Lancet $i$ : 8 (1962).

7. NyHAN, W.L.: Unpublished data.

- 8. Nyhan, W.L.; Oliver, W.J. and Lesch, M.: A familial disorder of uric acid metabolism and central nervous system function. II. J. Pediat. 67: 257 (1965).

9. Oski, F.A. and Growney, P.M.: A simple micromethod for the detection of erythrocyte glucose-6phosphate dehydrogenase deficiency. J. Pediat. 66: 90 (1965).

10. Platou, R.: Personal communication.

11. REeD, W.B. and Fish, G.H.: Hyperuricemia with self-mutilation and choreoatheotosis. LESCH-NYHAN syndrome. Arch. Derm. 94: 194 (1966).

12. Riley, J.D.: Gout and cerebral palsy in a 3-yearold boy. Arch. Dis. Ghildh. 35: 293 (1960).

13. Seegmiller, J. E.; Grayzel, A. I.; Laster, L. and LIDDLE, L. : Uric acid production in gout. J.clin. Invest. 40: 1304 (1961).

14. Shapiro, S. L.; Sheppard, G.L., Jr.; Dreifuss, F.E. and Newcombe, D.S.: X-linked recessive inheritance of a syndrome of mental retardation with hyperuricemia. Proc. Soc. exp. Biol. (N.Y.) 122: 609 (1966).

15. We are pleased to acknowledge the interest and participation in this investigation of the members of the JHLBC kindred. We also acknowledge the expert assistance of Mrs. Sharon Pesek, R.N., who participated in the field study, of Miss Pauline Schmidt, who carried out the blood typing, and of Mrs. Joanne Chislett and Mrs. Joan Machiz in the study of uric acid metabolism.

16. This investigation was supported by Public Health Service Research Grants No. HD 02609 from the National Institute of Child Health and Human Development and No. FR 00261 from the National Institutes of Health, General Clinical Research Branch and Public Health Service Training Grant No. T 1 HD 76 from the National Institute of Child Health and Human Development. 